\title{
A Rural Community's Livelihood Dynamic in the maintenance of a Mangrove Area as a Tourist Destination
}

\author{
Achmad Room Fitrianto \\ Sunan Ampel Islamic State University, Surabaya, Indonesia, ar.fitrianto@uinsby.ac.id \\ Andriani Samsuri \\ Sunan Ampel Islamic State University, Surabaya, Indonesia, andriani@uinsby.ac.id
}

Follow this and additional works at: https://scholarhub.ui.ac.id/ajce

Part of the Business Commons, and the Social and Behavioral Sciences Commons

\section{Recommended Citation}

Fitrianto, Achmad Room and Samsuri, Andriani (2021). A Rural Community's Livelihood Dynamic in the maintenance of a Mangrove Area as a Tourist Destination. ASEAN Journal of Community Engagement, 5(1), 105-129.

Available at: https://doi.org/10.7454/ajce.v5i1.1090

Creative Commons License

(c) (i) (2)

This work is licensed under a Creative Commons Attribution-Share Alike 4.0 License.

This Research Article is brought to you for free and open access by the Universitas Indonesia at ASEAN Journal of Community Engagement. It has been accepted for inclusion in ASEAN Journal of Community Engagement. 


\title{
A Rural Community's Livelihood Dynamic in the maintenance of
}

\author{
a Mangrove Area as a Tourist Destination \\ Achmad Room Fitrianto ${ }^{*}$, Andriani Samsuri ${ }^{1}$ \\ ${ }^{1}$ Sunan Ampel Islamic State University, Surabaya, Indonesia \\ *Correspondence email: ar.fitrianto@uinsby.ac.id \\ Received: June $5^{\text {th }}, 2020$, Accepted: July $2^{\text {nd }}, 2021$
}

Abstract This study identifies the problems faced by the residents of Banyuurip village and their adaptation efforts in preserving their mangrove areas. This paper aims to portray the community behavior dynamic in conserving the environment in line with the growth of pop culture in the social media era. Three components will be examined: first, the way people behave toward their environment; second, the economic pressure and the resources maximizing process, and the last component being the environmental issues that are framed in local political ecology. This paper uses the following five phases identified by the Sustainable Livelihood Framework (SLF): identifying vulnerabilities in the community, mapping the livelihood assets of the community, observing the transformation of structures and processes, identifying strategies implemented by the community, and formulating solutions. The SLF approach is useful for removing traditional barriers and is able to evaluate and modify the approach taken to follow the latest trends in society, by enriching the information gathered through this participation. This paper's findings maintain that the mangrove conservation area in Banyuurip Village reassures the community of its potential use as conservation land and an alternative source of livelihood. However, the manpower required to conserve the mangrove consists mainly of senior residents and is partially supported by the younger generation. Conserving mangroves requires a lot of funds and is an arduous process. It requires support from several parties, such as local companies, mining companies, universities, government agencies, and others.

Keywords: Mangrove Conservation; Participatory Development; SLF; Banyuurip Village; livelihood.

\section{Introduction}

Banyuurip Village, Ujung Pangkah, Gresik is one of the six villages that was pinpointed as a rural tourism development area by the Gresik Regency Government, in 2018. The villages that are pinpointed for rural tourism development have permission to develop a tourist attraction base in their own natural and cultural capacity. Based on this capacity, Banyuurip Village has two resources that could be of benefit in its development as a tourist destination; the first one is the geographical position of Banyuurip Village on the coast, and the second one is the existence of its extensive mangrove area of around 60 hectares. 
The process of pinpointing Banyuurip Village as a rural tourism development area by the Gresik Regency Government was started by a preliminary study conducted on the village by The State Islamic University of Sunan Ampel Surabaya that was supported by the Community and Village Empowerment department of Gresik Regency. Six problems were identified in the survey, including precinct/hamlet development disparities; weak youth leadership; disputes among green mussel cultivators, workers, and the village government concerning the Mangrove Center development; a lack of understanding of the Mangrove Center's function; and the oloran land dispute. These problems are depicted in Figure 1.

In addition to those six problems, the rapid industrial development on the north coast of Gresik has caused mangrove areas to gradually reduce due to the local authority converting the area into an industrial area. This can be seen through the construction of integrated industrial ports and beach resorts in the Gresik, Lamongan, and Tuban Regencies. Those changes of area functionality create more domestic waste that ends up in river siltation, sea abrasion, and damage to coral reef ecosystems. In addition, this severe situation makes coastal communities vulnerable and marginalized.

The condition of coastal communities, which are marginalized and have less government attention, requires communal creativity and innovation to break down the barriers. Franken and Bauers (2002) categorize as creativity the ability to identify and recognize problems and changes and the ability to find solutions. Moreover, creativity can be considered as the ability to have adaptability, diversity, flexibility, efficiency, cohesion, control, and connectedness in order to develop and measure resilience (Fiksel, 2006; Pettit, Fiksel, \& Croxton, 2010; Ponomarov, 2012). The term "creativity" also includes political and economic aspects.

Mangroves, as coastal ecosystems, contribute significantly to environmental sustainability. Having a good and sustainable environment means that the environment is able to support the community's needs as both a food bank and in its conservation functions. Underpinning those statements above, Suparmoko (2006) and Remoundou et al. (2009) demonstrate six functions of mangroves, including extraction, non-extraction, environmental conservation, biological conservation, and various social functions.

The mangrove's social function refers to the mangrove's use as an activity area for the community. For example, the mangroves in Banyuurip Village, which were developed eight years ago when Banyuurip was led by Ikhsanul Haris Village Head, have functioned as a tourist area. This mangrove area is equipped with an exotic bridge and jogging track along a one-kilometer stretch. In the middle of the mangroves there is also a gazebo and a reading garden. Furthermore, the community of Banyuurip also uses the mangrove as a sanctuary for 
monkeys, bekisar chickens, and pigeons. One of the main attractions to be found at this location is the traditional fishermen that cultivate white and green mussels offshore.

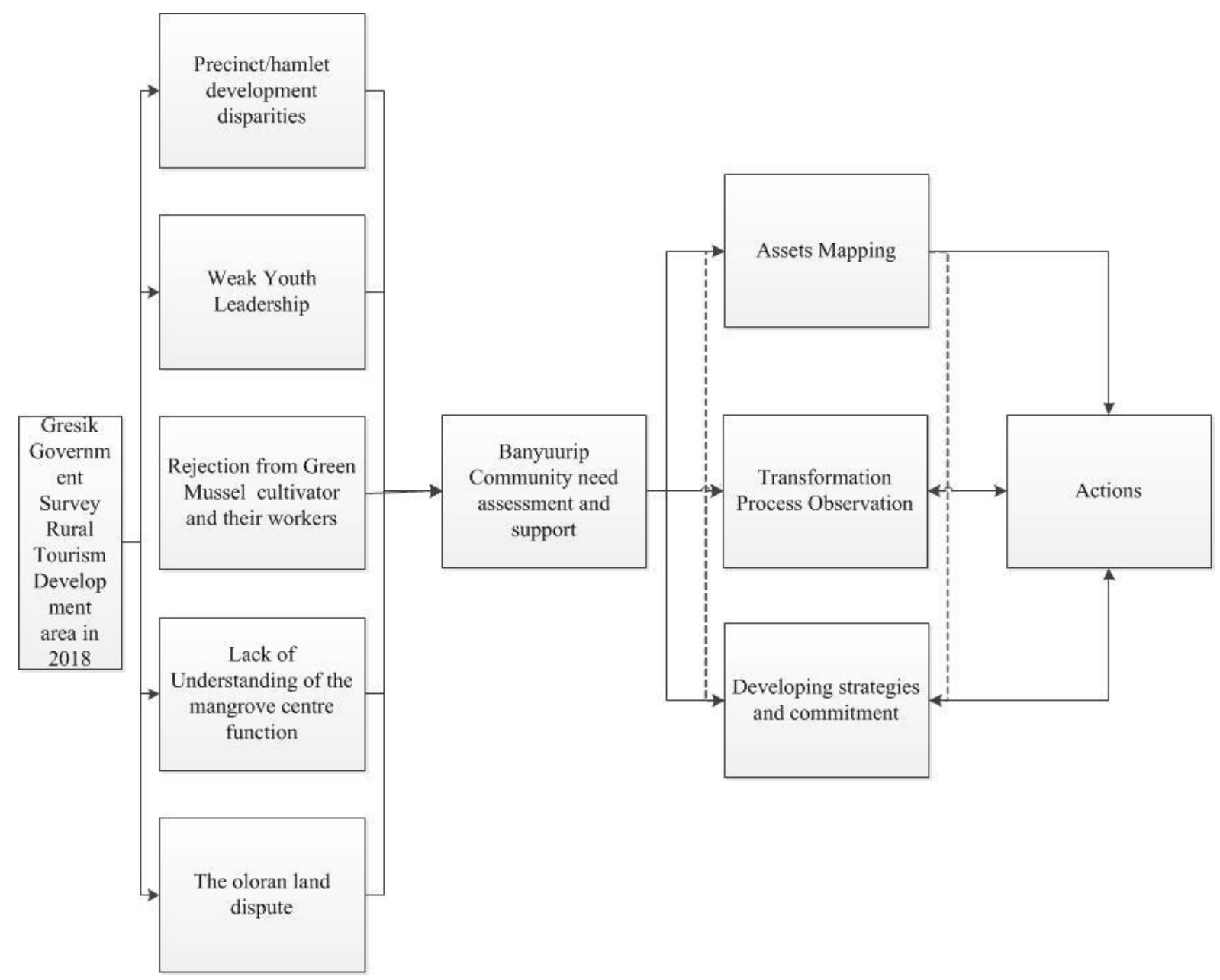

Figure 1. Problem Identification

Source: Field Observation (2019)

There are 345 fishermen who work in the Banyuurip bay area whose main activities are cultivating green mussels. The mussels are bred at sites located about $10 \mathrm{~km}$ from the shoreline. The fishermen start work at dawn and return to the bay at $11 \mathrm{am}$. In the afternoon, they return to clean the boats and make preparations for the following day.

Regarding those activities above we can see that the concepts put forward by Suparmoko (2006) and Remoundou et al. (2009) have been demonstrated in Banyuurip. The Banyuurip community has learned the value of having mangroves as part of their conservation and social functions from The Wonorejo Mangrove centre in Surabaya. The Mangrove Center of Wonorejo Surabaya uses the mangroves as a conservation area and local entertainment 
center. For example, the benefits gained from mangroves, besides fortifying the aquaculture and increasing the wood supply, also include ecotourism activities. Moreover, mangroves also function as a food source providing ingredients for making syrup, dodol, or mangrove flour. These products are made from two types of mangrove fruits, Sonneratia Caseolaris (bogem or pedada in the local language) and Bruguiera Gymnorrhiza (lindur).

Vatria (2013) stated that mangrove deforestation has caused erosion in several regions of Indonesia. The mangrove deforestation processes originate from the aquaculture activities that convert the mangrove areas into ponds for aquaculture. Many aquaculture cultivators utilize "oloran" soil, which is found along estuaries, as aquaculture pond soil. As a result of those activities, soil quality degradation occurs in the estuaries. Oloran is "new" land that is formed in estuaries as a result of river sedimentation.

According to Giesen, Wulffraat, Zieren, and Scholten (2007), the "oloran" soils have been created by river sedimentation. The "oloran" land is suitably fertile for mangrove seedlings to grow and ultimately stabilize the sedimentary soil and, eventually, the mangrove could be a natural fortress against sea abrasion.

Ujungpangkah Mangrove, located in an estuary of the Bengawan Solo River, has benefited from the additional land that has built up in the estuary that has made these areas very fertile. The use of mangrove land in Banyuurip Village has been quite dynamic. Open management and participatory approaches have been required in accommodating the numerous interests within this area. The pattern of stakeholder relations in mangrove management can be seen in Figure 2.

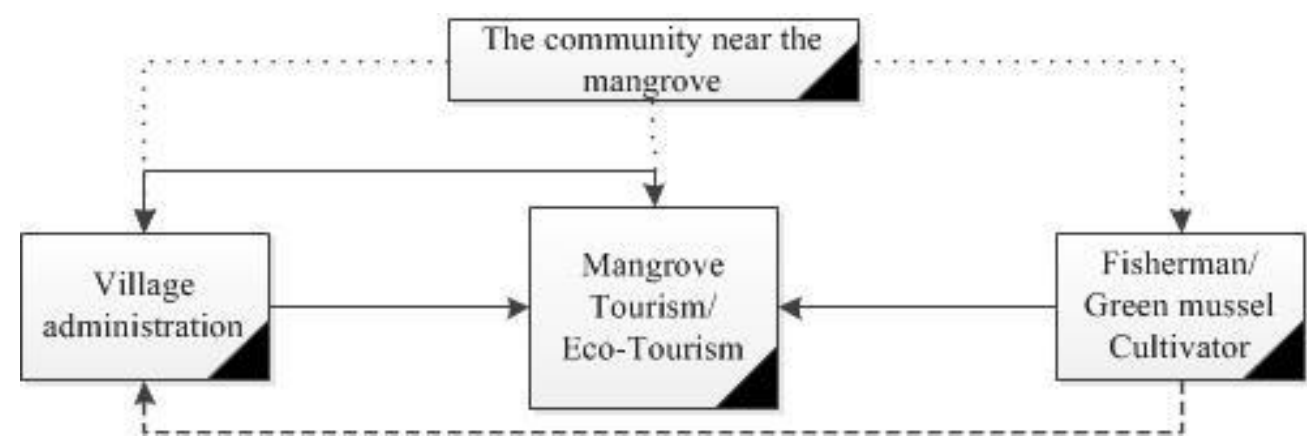

Figure 2. Patterns in the Stakeholder and Fisherman Relationship

Source: Field Observation (2019)

Notes: The solid line is a hierarchy and command line. A broken line is a relationship/ communication line that requires mediation. The dotted lines show the dependency. 
Franken and Bauers (2002) state that to be able to adapt to change, individuals or groups must be able to produce new methods or alternative communities to ensure their businesses and livelihoods remain safe. In the case of managing the mangrove areas and the activities of the Green Mussel culture, this requires a two-way dialogue to face the environmental changes. According to Franken and Bauers (2002), the factors that support a community's ability to face changes, include increasing the degree of flexibility within the community, tolerance for changes in people's habits, and cultural activities that tend to obstruct development.

During the early stages of the mangrove park development as a tourist destination, there was some dispute between the community and village administration about the mangrove land management. The location of the mangrove forest intersected the activities of the Green Mussel cultivators/fishermen and the proposal to develop a tourist destination in the mangrove. Some fishermen were in support of the mangrove as a tourist destination, and some were opposed to it. In order to be able to create a sustainable program in the mangrove area, the opinions of these two groups of fishermen were required. Aside from those two groups, there is a third group that has an interest in the mangrove area. This group consists of land brokers, who had the potential to sell off the land to foreign investors for the construction of recreational facilities.

In this study, we have observed the reactions to the mangrove conservation efforts from the behavior of the stakeholders, the fishermen groups, and the condition of the mangroves. The reaction of those stakeholders is influenced by their level of awareness of the importance of mangrove functions. This level of awareness is built from experience, current knowledge, and openness of networks and information. Blaikie and Brookfield (1987) see the main analytic approaches in political ecology focused on the following: (1) the way people behave towards their environment. The issue of "marginalization" of the economy, which has given rise to the term "for the sake of creating a kitchen smoke collapsing", is often exploited by the environment; (2) the problem of production pressure and resources.

The number of people (mostly the poor) who, depending on natural extractive efforts, on the one hand, become the granary in the election, and on the other hand, become the side of economic sustainability to make environmental issues become ecological and political issues; (3) environmental policy issues that are not covered in political promises and power struggles. The three problems above create a "situational rationality" that has the potential to force land users to reduce their exploration of the environment because they are in a state of despair (Blaikie \& Brookfield, 1987). From some of the arguments and facts above, we can 
see that the distribution of village assets and all their potential needs to be constructed in order to build community economic independence.

\section{Methods}

This paper covers four aspects, namely, the study of political ecology, public policy, human behavior, and sustainability. Therefore, the approach taken is based on the Sustainable Livelihood Framework (SLF). The SLF will function as a methodological framework and analytical tool to investigate the main problem in this research. This framework identifies how, and by what means, local communities respond and adapt to the limitations and vulnerabilities they are faced with in order to seek welfare improvement. The research and community engagement program duration was seven months that start at end of May 2019 and finished at December 2019.

The SLF was created to understand, holistically, the various causes of poverty, in order to develop a complete solution (Chambers \& Conway, 1992; Dent, 2013; DFID, 1999; Ludi \& Slater, 2008; Scoones, 2015). By understanding those various causes, the solution offered would assist marginalized people by enhancing their lifestyle through sustainable activities.

There are five SLF phases, namely, identifying vulnerabilities in a particular community, mapping the livelihood assets owned by the community, observing the transformation of structures and processes, identifying community strategies, and formulating the results of solutions (Chambers \& Conway, 1992; Dent, 2013; DFID, 1999; Ludi \& Slater, 2008; Scoones, 1998, 2009, 2016). The five phases of SLF, referred to in this research, analyze the five major elements of strategy, mentioned by Hambrick and Fredrickson (2005).

The use of SLF as a methodological approach is based on the five stages, carried out objectively, involving the values adopted in the community and will be confronted with the introduced values of renewal. Therefore, SLF as a participatory approach, according to McNiff (2010), is a methodology that involves community values and emotions. Therefore, the involvement of community group representatives is the key activity. In line with their hypothesis, McNiff (2002) and Creswell (2018) provide three paradigms in conducting participatory information gathering. First, the questions asked can begin by pointing to social facts that can be a reaction from the community when natural or social phenomena occur.

Second, the practical policies that have been applied and carried out in everyday life, have been accepted as the center of knowledge, and the third is that the stage of information retrieval is to be established with the aim of encouraging personal and social change. 
Therefore, in participatory information gathering there must be a high level of community involvement.

There are three groups of people who are the sources of information in writing this paper, namely, a group of fishermen, the government (Village/District/Regency) and the local community. These three elements of society are an important part of the decision-making process related to mangrove issues in Banyuurip Village.

This methodology uses three reasons for community participation in its information gathering. First, by involving representatives from the community as informants, this participatory approach will make it easier to record the ongoing social transformation (Carr \& Kemmis, 1986; Fitrianto, 2019; Kemmis, 2014; Koshy, 2010; Pedretti \& Hodson, 1995). By involving local leaders in the process of extracting information, traditional barriers can be removed, and we are able to evaluate and modify the approach taken to follow the latest trends in society.

Second, actively involving community groups also functions as part of the process of raising awareness and increasing community awareness in understanding the social phenomena that we are writing about (Carr \& Kemmis, 1986; Fitrianto, 2019; Kemmis, 2014; Koshy, 2010; Pedretti \& Hodson, 1995). The last reason is that it will enrich the information extracted because it involves all the perspectives that exist in the community (Koshy, 2010).

\section{Results and discussion}

\subsection{Livelihood dynamic of Banyuurip}

The people of Ujungpangkah Gresik lead a harsh and physically demanding lifestyle which is evident from the way they make their living, such as working in limestone mining and breeding mussels offshore. The recent dynamic economic environment, which suffered coastal area damage, has forced the community to take urgent action. This change requires changes to livelihood strategies and various activities, and this article explores the livelihood changes that have occurred. Vulnerability and hardship cases in Banyuurip Village have been identified through community service programs, provided by UIN Sunan Ampel. There are five recursive steps, depicted in Figure 3. First, identify factors that cause social disruption and community vulnerability. In this case, river siltation, sea abrasion and damage to coral reef ecosystems.

The second means is anticipation of the problems that will arise. The anticipation process starts by inviting residents to discuss the concepts that will be put forward, thus creating awareness. At this stage, community discussion, or Musrenbangdes, as it is better known, is a 
key starting point for articulating development ideas that have emerged. Apart from the Musrenbangdes, involvement by the universities and other social organizations outside the village become a factor that supports the development of community awareness. This paper has recorded that the residents of the village of Banyuurip are taking early action on the prevention of damage to the coastal area of Ujungpangkah and its surroundings, through the development of the Mangrove Center Park located at the estuary of the Bengawan Solo River, in the village of Banyuurip.

The third means is coping capabilities. At this stage, the dynamic processes between various elements in society come into play in order to address the problems that arise. After experiencing the negative aspects of environmental degradation, the community creates a better environment, such as creating a mangrove conservation center. At this stage, we can see the results achieved by having the full support of community groups, and this is reflected in the formation of tourism awareness groups with a representative from each village precinct managing the mangroves. Furthermore, the village government very much supports the Mangrove Center Park through the development of a new access road from the main road of the village to the mangrove area. This new access road was village owned ponds and it partially has been backfilled and used for road access. The new access road is six meters wide and 260 meters in length. The cost of backfilling was 180 million rupiahs, which originated from the village fund.

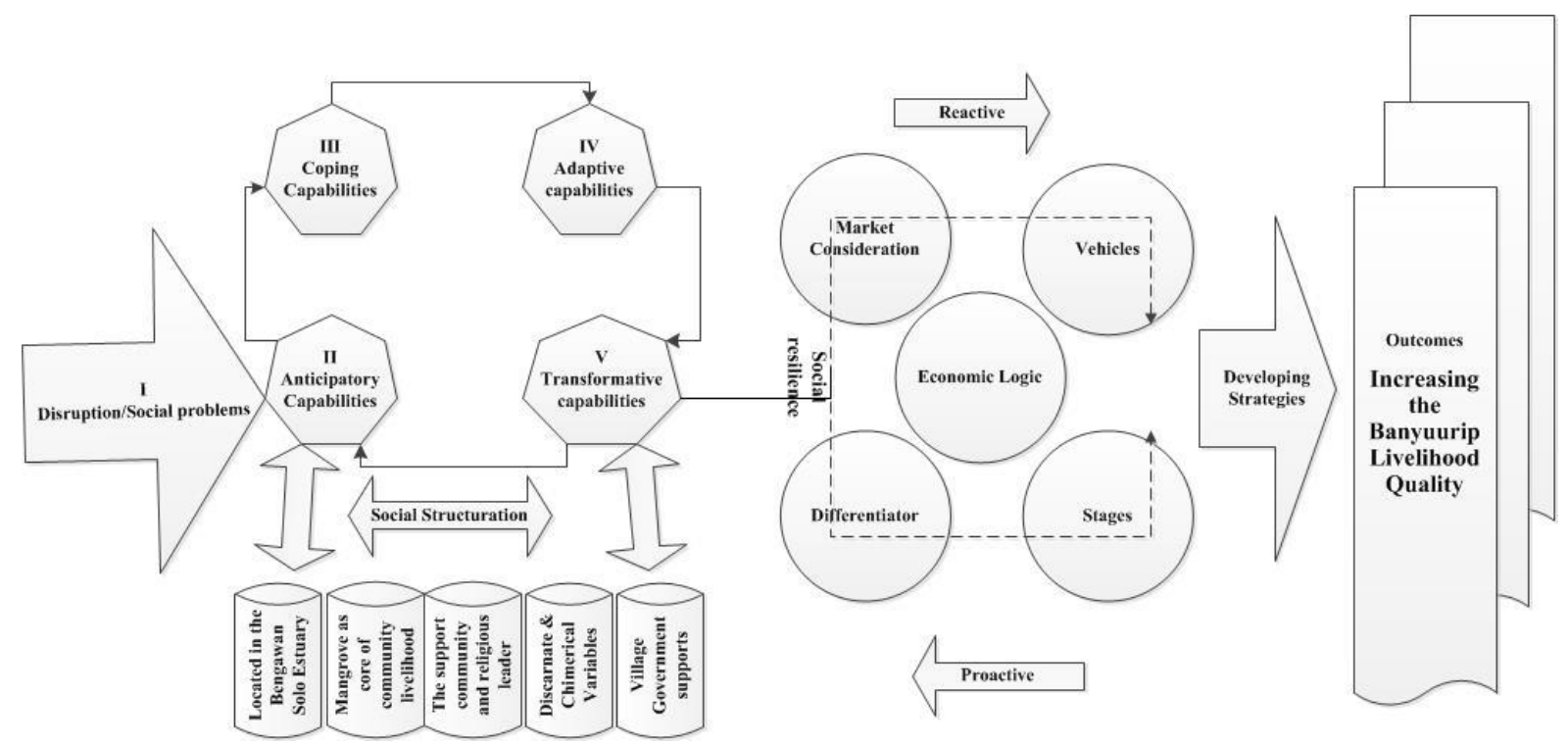

Figure 3. The Livelihood Dynamic of Banyuurip

Source: The model adopted from Hambrick and Fredrickson (2005), Menzies and Raskovic (2020), and Scoones (2015) 
The fourth means is adaptive capabilities. At this stage, the community and government officers make adjustments to the plan and try to reach a consensus to solve the problems that are causing coastal degradation, through the development of the Mangrove Park Center. The village of Banyuurip is also aware of the recent pop culture practices which are dominated by the millennial generation and driven by social media. Development of the mangrove park has become an Instagrammable event for Banyuurip villagers. The existing condition of the mangrove area, which is used as a docking area for fishing boats, and the dense mangrove forest make this place very suitable for enjoying the beauty of the sunset. The Banyuurip Mangrove Center has several social media accounts, including BlogSpot, Facebook, and Instagram, that it uses to promote the center.

The fifth means is the transformation of capabilities. At this stage, the transformation is carried out by every element of society who works hand in hand for promotion, development, and network building. In this stage, the roles of formal institutions, organizations, policies, and legislation that shape and determine the level of community behavior, are recorded. This stage identifies the extent of the bureaucratic barrier to be managed and identifies the participation process within the decision-making process in order to maximize the potential of the village and increase the livelihood of the community. The capacity for change in Banyuurip can be seen from the following three facts. First, is the involvement of the Village Owned Company (BUMDes) and the Tourism Awareness Group (Pokdarwis) in the community empowerment process. Both village organizations involve youth and female residents in their program to develop the village economy. For example, BUMDes, which is run by Banyuurip's housewives' group, provides funding for the production of crispy Kupang (green mussel meat) and mangrove stick snacks.

Second, is the involvement of PT PGN SAKA. PT Saka Energi Indonesia (PGN SAKA) is the upstream arm of PT Perusahaan Gas Negara (Persero) Tbk (PGN), Indonesia's largest natural gas transportation and distribution company. PGN SAKA has a drilling site located about seven kilometers from the mainland of Ujungpangkah, Java Timur. PGN SAKA and their NGO Partners, called PUPUK Indonesia and SPEKTRA, have an important role in the development of the Banyuurip Mangrove Center. The fund and programs have been provided since 2015. The programs that are run are the establishment of the Mangrove Education Center, irrigation maintenance, health, and education. In 2020, PGN Saka allocated around Rp 200 million in funds for Banyuurip Mangrove Center maintenance. 
Third, are community and religious leaders' roles in sustainable development. These include the local informal leaders of Banyuurip, who provide constructive advice and suggestions to residents that face economic and social problems, especially in the development of village tourism. For example, the role of the Mambaul Ihsan Islamic boarding school in village tourism development was the construction of a unique mosque which was built to resemble a ship. This mosque has become a recommended tourist venue when visiting Banyuurip Mangrove Center.

Once the problem is discovered, the ability to respond and adapt becomes the key. Cultural resources, such as values (i.e., ideology, local wisdom, education level and future direction of residents), norms (i.e., understanding the millennial behavior as well as the state rules and regulations) and schemas (i.e., increasing income and creating local tourism) are very important social resources (i.e., institutional trust, leadership, and social organization support) that also play the same role.

\subsection{Banyuurip Livelihood}

The Banyuurip Village area is 534.86 hectares and consists of 24.06 hectares of paddy land, 10.38 hectares of lawn area, 77.35 hectares of ponds, 391.07 hectares of dry land and around 32 hectares making up other forms of terrain. Banyuurip Village is two meters above sea level with rainfall of around $2000 \mathrm{~mm} /$ year, and an average temperature of $29^{\circ} \mathrm{C}$.

Based on the 2016 census, Banyuurip Village's population is 6,546, and is spread over around 1,600 households. The total male population is 3,264 and the total female population is 3,282. Banyuurip Village is in one of branches of Bengawan Solo River's estuary (Figure 4). This Village consists of 1,114 fishermen, 767 farmers, and 1,125 migrant workers. As many village residents are migrant workers with overseas experience, they are inspired to delve into creative business ventures to help develop their village, by creating, for example, a communal park.

The residents' consensus to plant mangroves with an intention to prevent sea erosion has been very beneficial. The mangrove has grown beautifully and become a new tourist destination in Gresik, which has been called Banyuurip Mangrove Center. The Banyuurip Mangrove Center is located on an area of about two hectares, equipped with three gazebo facilities and a jogging track or wooden platform 600 meters in length. Visitors can enjoy views of the mangrove forest from the wooden jogging track and the charm of the moored fishing boats makes it rather picturesque. Visitors to this mangrove tourism park, are also 
able to enjoy the nursery area, which consists of cypress trees and mangroves, and includes approximately 60 thousand mangrove seedlings.

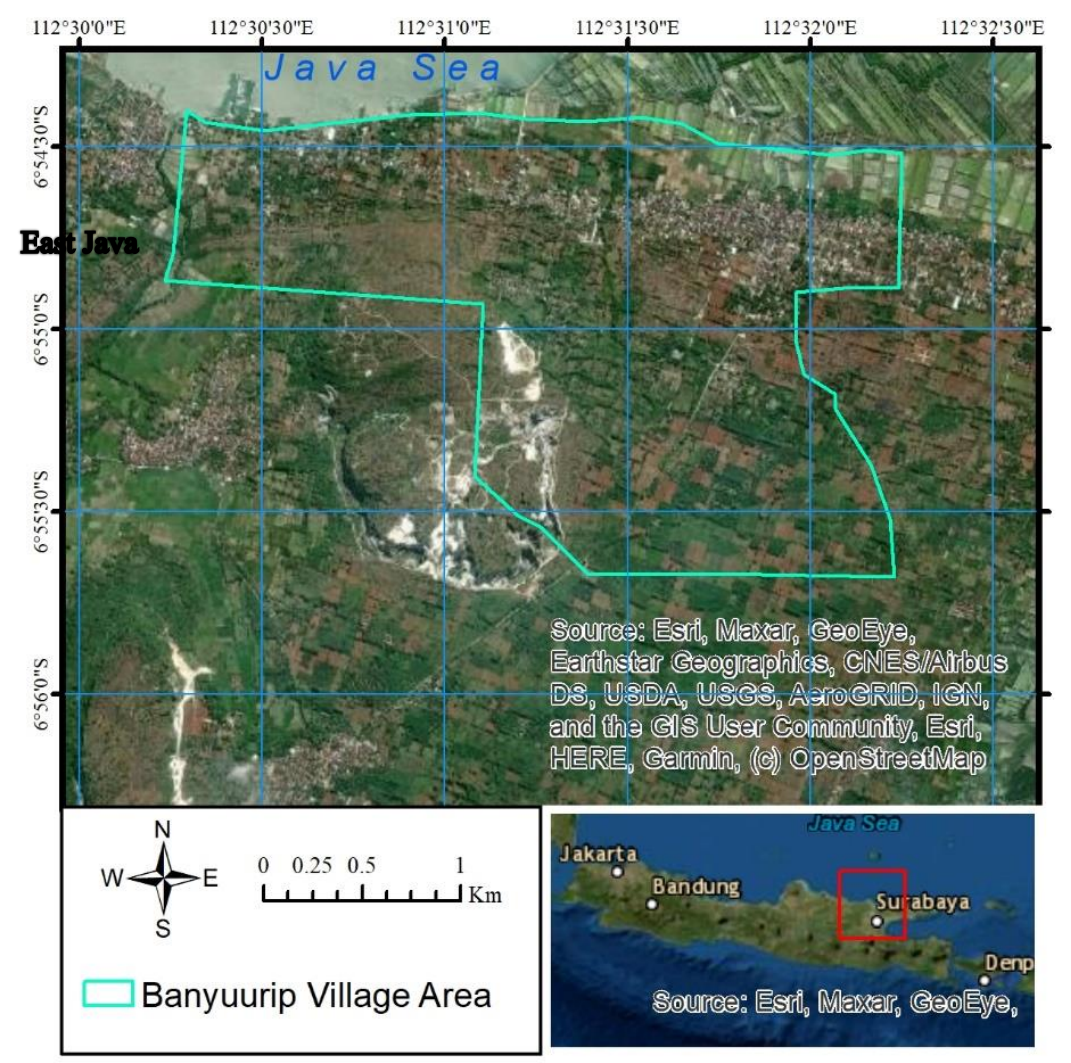

Figure 4. The Map of Banyuurip Village

The Banyuurip Mangrove Centre area has also been functioning as a fishing port area, where fishermen anchor their boats and distribute their green clam cultivation products outside the village, and as the village government supports both roles, namely, as a leisure center and as a clam production centre, an entrance road has been widened by backfilling the village reserve land to provide better access to the location.

The existence of the Mangrove Park Tourism Development initiative in Banyuurip Village also benefits the surrounding community and improves the welfare of the residents and fishermen. This increase in local community welfare is evidenced by the extra income they derive from servicing the visitors. The fishermen rent out the boats for visitors to cruise the estuary up to the green clam cultivation area.

Besides renting the boats, the community also derives income through parking fees. Motor bikes need to pay 2,000 rupiahs and 5,000 rupiahs are charged for cars. On average, this 
mangrove area has around 300 motor bike visitors and around 100 car visitors in a month. In total, parking fees are able to raise up to 11,000 rupiahs a month.

\subsection{Obstacles}

Nonetheless, turning the Bengawan Solo River estuary in Banyuurip Village into a mangrove park has encountered several problems. These obstacles have been raised by residents when asked about the difficulties in developing mangrove tourism areas.

The village chief of Banyuurip Village has provided an example of their financial difficulties in developing a 30 meter jogging track in the mangrove area. This project, it seems, requires around 150 million rupiah, whereas the same amount could be used to build an entire magnificent house. The cost of development in the mangrove area is expensive due to having to use Bengkirai wood, a strong wood that can be used in salt water, but which is very expensive. Therefore, in order to build an appropriately long jogging track requires a considerable investment.

Apart from the financial problems, the focus-group discussion, that was conducted during fieldwork, revealed that human resource factors were also in need of further attention. Developing a tourist attraction, such a mangrove park, requires creativity and innovative human resources, and concerns two people who are involved in the daily activities of the Mangrove Park, the senior fisherman and his son. Few of the young residents of Banyuurip are interested in working with the mangroves and prefer to seek jobs outside the village. In short, The Banyuurip Mangrove Center lacks capable human resources to support the development of the Mangrove Center, in terms of marketing and innovation to attract tourism.

The other obstacles identified during fieldwork observation were that the park requires several physical facilities. For example, as the park has many visitors during the peak school holiday season, it becomes very crowded and disturbs the activities of the fishermen in harvesting the green clams. Not only do visitors have to queue for lengthy periods to access the boating services, due to a shortage of boats, but there is also a need to widen the road to improve access to the mangrove tourism sites. Just as importantly is the requirement for a children's playground in the mangrove park to serve both as a playground and a place to wait one's turn to boating and exploring Bengawan Solo estuary.

Along with Gresik District's decision to create a tourism development area in the Ujungpangkah sub-district involving six villages, the decision has created competition between the villages within the Ujungpangkah area. Aside from Banyuurip Village 
developing its Mangrove Center, Sekapuk Village is developing SETIGI, Gosari Village is set to develop WAGOS, and Pangkahwetan Village will be developing fishing and river tours. Each tourist destination owned by those villages is creating competition between the villages for the number of tourists they can attract to each village. The development of tourism is aimed at improving the welfare of the community, however, to some extent, the development of the tourism sector that invades and changes the natural environment may also threaten it. Environmental quality would decline due to waste problems, excessive use of groundwater, vandalism, destruction of natural biota because of hotel establishments, as well as other impacts.

\subsection{Why create the Mangrove Park?}

Physical and geographical aspects of a location are not only referred to in the local literature but also embedded in its identity and local culture (Gieryn, 2002; Thomas, 2000). Stedman (2003) shows how changes in the local natural environment induce changes in people's behavior. The degree of change is identified through people's dependency on certain environmental characteristics. Underlining those beliefs, Devine-Wright (2013) conducted a major review of society's position in response to climate change, and focused on identity and attachment as adaptation, resilience, and transformations of different scales.

The Banyuurip community is considering the mangrove park in response to the threat of coastal degradation, based on five reasons. The first is economic reasons. Creating tourist sites that can be managed by the local residents allows them to generate additional income.

An example, that can be used as a reference, is the village of Ponggok Klaten that has the Umbul Ponggok tourism sites, and Pujon Kidul Village that can portray rice fields as beautiful and Instagrammable tourist sites. These two villages inspire and motivate Banyuurip Village to explore its potential. Aside from being a source of income for the village government, it can also provide hope for its residents to take part in sustainable development.

The second reason involves market considerations. The location of Banyuurip Village is on the North Coast of the Java Line (pantura) and this makes this area very accessible despite the fact that at one time the pantura had very bad congestion.

As new tourist destination it is feasible to expect it to have 4000 visitors a year, for two reasons. The first reason is that the Banyuurip Mangrove Park is located near the main road that has several famous tourism attractions, such Delegan Beach, and WBL tours in Lamongan. The second reason is the existence of the construction of JIIPE in the Manyar 
area. The construction of this new port city in Manyar will also be a supporting factor for the development of tourism in Ujungpangkah Sub-District. At this point the market consideration is categorized as chimerical and incarnate.

The third reason for developing the mangrove park in Banyuurip is based on its social support system. Harvey, William, and Krista (2000) and Kaufman and Kaliner (2011) explain that featuring places of interest, based on their human activity potential, is a good way to highlight their natural environmental characteristics. The village government contributes by providing a development plan of the sites. There is also a group of youth that supports the development of the tourist destination. The government officers and youth groups of the village play a part in the development of public awareness of the village's tourism potential. This argument, along with the idea put forward by Williams and Patterson (2007) and Haywood (2014), highlight the importance of the roles played by the biophysical and sociocultural aspects of a place.

The fourth reason is based on corporate factors. Support from higher government institutions, demonstrated through the upgrade and maintenance of road access to the tourist attraction location, is the key to success. Support from the district government for improving village and district roads will indirectly facilitate access by tourists who travel to the tourist site. The last reason is based on the uniqueness of the village. This uniqueness is categorized as metaphysical. The combination of beautiful limestone hills, the beaches, the conservation center, and the magnificent mangrove forests can all be part of what is offered during one visit to Banyuurip Village.

The five reasons, that are depicted in Figure 5, represent the concepts of Banyuurip with regard to adaptation, resilience and transformation, that appear in people's minds when they think of its environment, and which affects community responses to change (Haywood, 2014; Iain \& Fikret, 2003) 


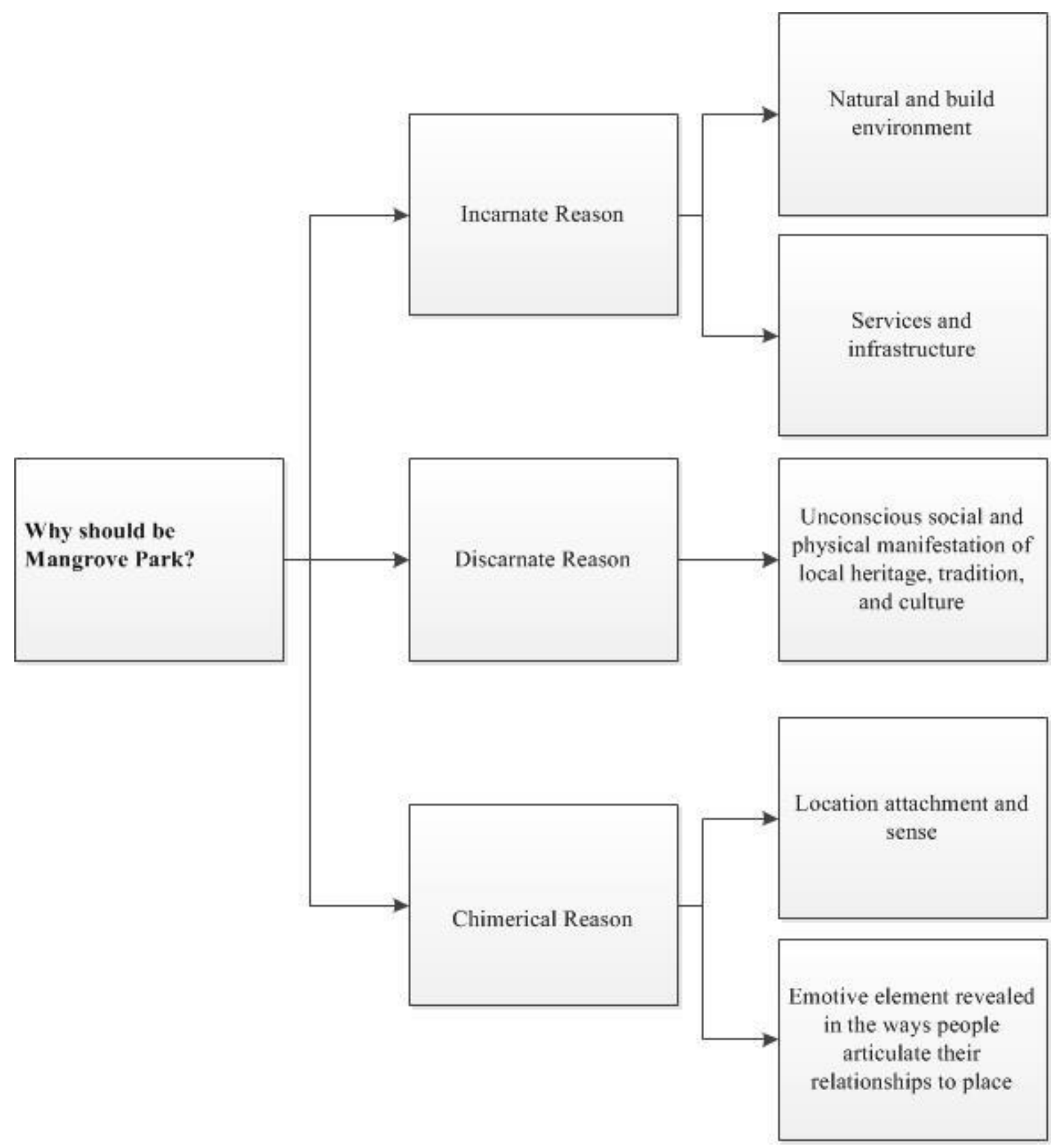

Figure 5. The Location Consideration

Source: Adopted from Thomas (2000) and Williams and Patterson (2007)

\subsection{Transformation's process and resilience}

The sections above have explored the existence of the social structure that was put in place in Banyuurip Village in the establishment of Mangrove Park as the main project for improving the Banyuurip lifestyle. The five major elements of strategy in use, as explained by Hambrick and Fredrickson (2005), include arenas, differentiators, economic logic, vehicles, and staging. This section discusses the reactive and proactive parts of social resilience that occurs, and which is depicted in the second part of Figure 3. 
The first element is arenas. Geographically, Banyurip Village is bounded on the north by the Java Sea, as depicted in Figure 4, creating a beautiful beach and having an abundant mangrove area. The entry fee for Banyurip Mangrove Center is 3,000 rupiah per person, which is relatively cheap and suits the middle-income visitor who wishes to experience the mangrove scenery. Therefore, the Banyurip Mangrove Center target market is Indonesia's middle economic class.

The second element is differentiators. There are three advantages pertaining to Banyuurip as a rural tourist destination. First, is the abundance of beautiful mangroves that cover an area of 60 hectares consisting of approximately 60 million mangrove seedlings and offering a unique educational tourist attraction. Second, is the geographical location of Banyuurip, which consists of agricultural land, beaches, and limestone hills, offering one-stop tourism. The scenery at the top of Banyuurip's limestone hill appears to be enhanced by the "green belt of mangroves." This position is ideal for enjoying the beach and sunsets, as well as the accompanying sound of seabirds flying from place to place, making this location deserving of being called "a piece of heaven in Gresik." Furthermore, the iconic Mosque of "Masjid Kapal" can be an alternative venue for daily prayer, and the mosque is also offering a unique chapel for marriage ceremonies or simply for social media photography. Third, the mangroves are a habitat for a variety of coastal organisms. Shellfish and crabs are two species that breed in mangroves. Along with sustaining the mangrove areas, Banyuurip Village residents also support the cultivation of green mussels. Banyuurip is known as the center for the production of green mussels in Gresik. The majority of Banyuurip's fishermen are employed in green mussel production. Due to the cultivation of green mussels, there are three attractions on offer, namely, boating to the green mussel cultivation station, which is located around 10 kilometers offshore, the rows of moored fishing boats that create photo opportunities, and the weighing and auction processes of the green mussels.

The third element is economic logic. Banyuurip Mangrove Center offers various attractions. The beauty of the mangrove area that can be seen from a beautiful two $\mathrm{km}$ wooden jogging track, the line-up of exotic boats, the green mussel auction, and an affordable entrance fee will attract a large number of visitors to Banyuurip. The more tourists that visit, the more money the residents of Banyurip earn. Besides the entrance fee, the community is also able to earn money from the provision of culinary services and the selling of souvenirs. In addition, the mangroves also provide a reserve income for fishermen when the high tide season arrives, and they are unable to cultivate green mussels offshore. The fishermen would be able to earn an income from scavenging crabs and mangrove clams. In short, the more 
sustainable mangrove areas that are developed, the better the quality of lifestyle of the community.

The fourth element is vehicles. This stage involves the implementation detail which is a step towards reaching the target market. Past experience with mangrove deforestation and conflict of interest among groups of people in the management of mangroves have taught the Banyuurip community how to deal with environmental issues. Consensus among community groups, who have experienced development disparity in the past, has made the process of creating a village tourist destination easier. Involving the community in the operation of the mangrove center creates a feeling of "belonging to the mangrove." Reducing conflict and creating harmony in the village allows the village development process to proceed smoothly. When harmony has been achieved, and the tourist attraction developed, the next step is to promote the tourism objects. In the current social media era, it is imperative to use social media for marketing. At this stage, the Banyuurip Mangrove Centre has social media accounts that are managed by village officials who provide information related to the location and/or condition of the village. Therefore, social media content must be creative, interactive, and innovative to pique the interest of potential visitors, including national and international visitors. When targeting national and international visitors, it is essential to collaborate with national and international tourist agents.

The last element is staging. The first variable in the decision to stage, is driven by the available resources and the support provided. The first stage involves having a strategic location and support from the regional government, through the Gresik Government decree for the Ujungpangkah rural tourism development area, and a government owned company, such PGN SAKA. The second variable is priority. This implies that fast and aggressive decision-making is often required when several windows of opportunity are presented. For example, the mangrove center development has attracted interest from some investors, but for some reason, the village officer, who wanted to collaborate with others before making a decision, rejected the investors' proposal to invest in the Banyuurip rural tourism development. The third variable is credibility and leadership. Trust in the Banyuurip Village officers has been established for the last seven years, providing a huge advantage. At the moment, Banyuurip Mangrove Centre serves as an Essential Ecosystem Area that is supported by the province government. The last variable is the pursuit of early wins to gain a foothold in achieving bigger goals. After the successful establishment as a conservation and educational village, we believe that Banyuurip Village will potentially become a premier tourism village, in the near future. 


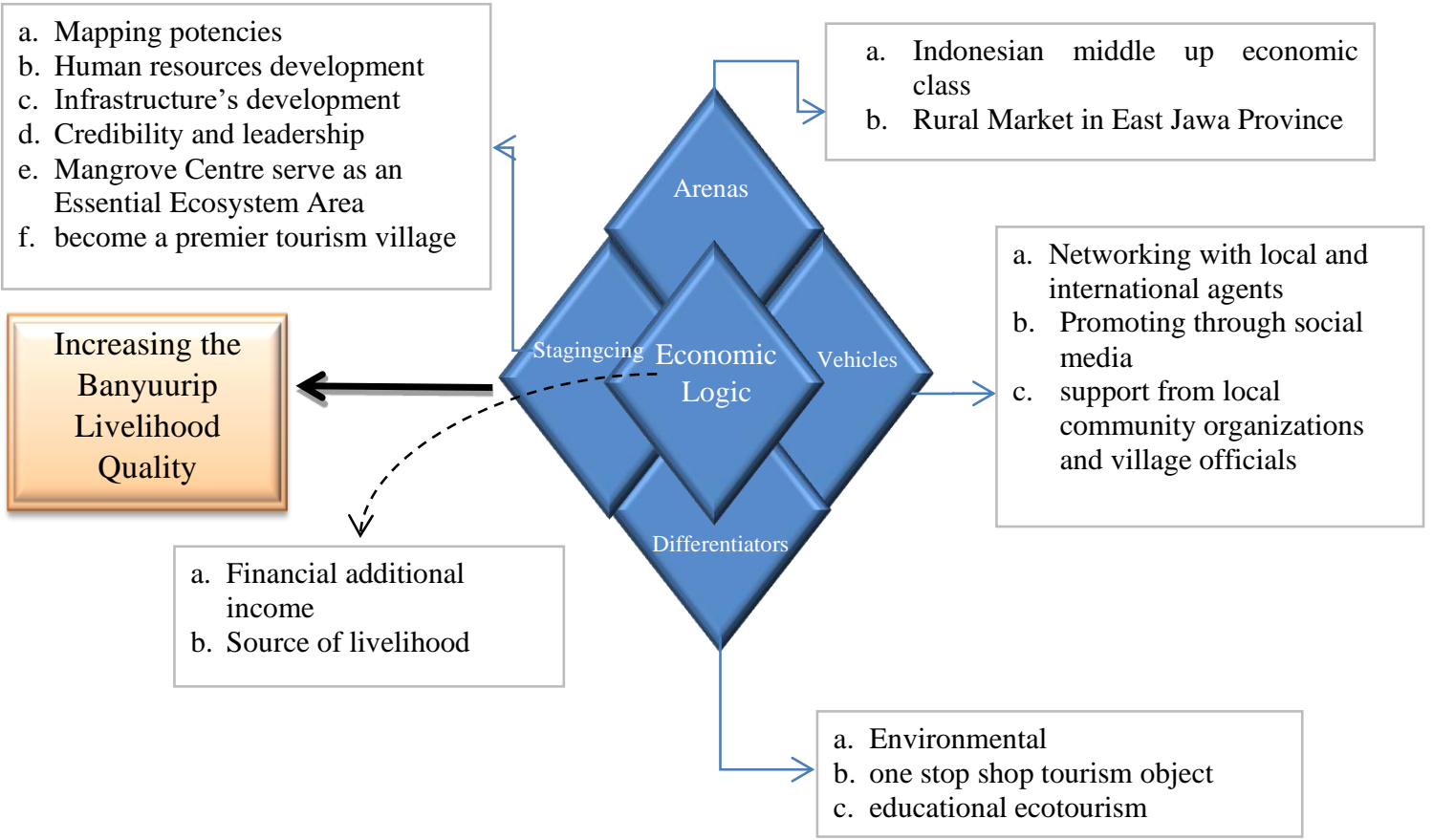

Figure 6. Five major elements of strategy

Source: Adopted from Hambrick and Fredrickson (2005) and field observation (2019)

Based on the strategy analyses that are depicted in Figure 6, the relevant plan for Banyuurip Village is to leverage the Banyuurip Mangrove Center as Indonesia's primary environmental educational park. However, political dynamics must be managed to build a strong social system. Olsson et al. (2015) stated that "a powerful depoliticizing or naturalizing scientific concept and metaphor, when used by political actors," can influence community loyalty. Furthermore, Parsons mentioned that there are four considerations for establishing a strong social system, as follows: (i) it needs to adjust to its physical and social environment and the natural environment in which it adapts to its needs (adaptation; conditions: development of industry and market, science and technology); (ii) its main goals must be clear and attainable (to reach the goal; condition: society needs to expand a political system); (iii) the interrelationships between its components must be coordinated and standardized, and efforts must be made to perform consistently (integration; conditions: development of civil society and religious beliefs); (iv) need to provide, maintain and renew themselves, and inspire their individuals to achieve their aims according to social and cultural expectations (latency period; conditions: development of families and schools) (Missimer, Robèrt, \& Broman, 2017; Parsons, 1951). 
In addition, the promotion of adaptation, independency and entrepreneurship can lead to inequality, lack of solidarity with those more unfortunate, lack of cohesion, and other negative effects that can be adjusted or offset by the government and civil society. For example, the government line is to guarantee equality and public interest, while emergency power is aimed at environmental changes. (Alexander, 2010; Cooper, 2006; Missimer, Robèrt, \& Broman, 2017)

Based on those five strategic elements, interdisciplinary coordination, and judicial and public-private sectoral organizational networking are needed (Hillyard, 2000; Kapucu, 2008; Missimer, Robèrt, \& Broman, 2017). It is not enough to have high-performance components in the system, namely, the connections between the components that make up or undermine the system's resilience (Boin \& t Hart, 2010). However, managing community opportunities and threats is very complex and involves coordination between the public and private sectors (Doerfel, 2015; Doerfel, Chewning, \& Lai, 2013). Within a society, many actors play a role in the creation and maintenance of capabilities, including individual-level capabilities and risk factors, as well as the local performance of social-level capabilities (for example, the quality and integrity of governance systems, population, and operating infrastructure). From the perspective of various sectors, government and non-governmental organizations, professionals and volunteers, companies, education institutions, religious groups, sports clubs, local or national media and other community participants, as well as charitable organizations, must unite to strengthen and utilize the economy enhancement, social funding, information and networking, and community capacity.

\section{Conclusion}

Community based tourism, that has been carried out by the Banyuurip Village community of Ujungpangkah, is very dynamic. This can be seen through the enthusiasm shown in building mangroves as the center of their livelihood, controlled by senior residents and supported by youth. Moreover, the dynamics that exist among the groups is determined by the different educational levels. Education level differences produce gaps in understanding of the aims of mangrove tourist development. At this stage, further recruitment of young creative people is needed to contribute at management level rather than as guides for this tourist area. Involving university students and having intensive visits from the main investigator could increase community confidence for developing and promoting the existence of Banyuurip Mangrove Center. In addition, a future program could be introduced to provide training and managing assistance for the creation of paving blocks made from the shells of the green mussels. 
In summary, however, the mangrove conservation area in Banyuurip Village promises high hopes to the community not only as conservation land but also as an alternative source of livelihood when the sea is less friendly to fishermen due to high tide season. The activities of the fishing community and the village facilitators who are developing this environmental tourism destination should be greatly appreciated because the management of mangrove tourism land is very draining and costly. The Banyuurip Mangrove Center, however, is managed independently by the village and the fishermen community. Nonetheless, it takes cooperation and support from various parties, such as local residents, local companies, mining companies, universities and government agencies, to succeed.

\section{Acknowledgment}

We would like to thank Dr, Abdul Chalik, Dr, Mugiyati, Dr. Ir. Muhamad Ahsan for the support and rigorous discussion, and FEBI UIN Sunan Ampel, a young researcher; Andy Permadi, Muhammad Andre Agustianto, Rianto Anugerah Wicaksono and others, including the Sunan Ampel students who were involved in this research.

\section{Funding}

The manuscript was part of the main researcher involvement in the community-based tourism assistance program in six villages in the Ujungpangkah District, that were supported by The Community and Village Empowerment Agencies of the Gresik Government, in 2018, and The UIN Sunan Ampel Research Center grant of 2019 on research titled "Konflik nelayan dengan pemangku lokal dan dampaknya terhadap pengembangan wisata mangrove (ecotourism) di Desa Banyuurip Ujung Pangkah Gresik"

\section{Declaration of Conflicting Interest}

There is no conflicting of interest for this manuscript.

\section{Author Contribution}

Achmad Room Fitrianto has contributed to the areas of conceptualization, methodology, formal analysis, investigation, writing and draft preparation, and project supervision. Andriani Samsuri has contributed to the areas of investigation, the validation process, manuscript editing and data curation, including providing the main suggestion in developing a SWOT analysis of the manuscript. 


\section{Short Biography}

Achmad Room Fitrianto can be found at https://orcid.org/0000-0002-8490-6816. He graduated from the Economic and Development Studies Program of Airlangga University for his undergrad studies. He also obtained two master's degrees from the Post-Graduate School of IAIN Sunan Ampel for his Masters of Islamic Economics and the School of Government and Management Murdoch University for his Master of Arts in Public Policy. Achmad Room also obtained his $\mathrm{PhD}$ from Curtin University.

Andriani Samsuri can be found at https://orcid.org/0000-0001-7677-1256. She graduated from the Business Administration program of Brawijaya University for her undergrad degree and obtained her Magister Management from the same university. Andriani obtained her Doctoral Degree from Airlangga University in Management Studies.

\section{References}

Alexander, D. E. (2010). The L'Aquila Earthquake of 6 April 2009 and Italian Government Policy on Disaster Response. Journal of Natural Resources Policy Research, 2(4), 325-342. https://doi.org/10.1080/19390459.2010.511450

Blaikie, P. M., \& Brookfield, H. (1987). Land degradation and society: London: Methuen.

Boin, R. A., \& 't Hart, P. (2010). Organising for Effective Emergency Management: Lessons from Research. Australian Journal of Public Administration, 69(4), 357. https://doi.org/10.1111/j.1467-8500.2010.00694.x

Carr, W., \& Kemmis, S. (1986). Becoming critical: education, knowledge, and action research. London Philadelphia: London Philadelphia: Falmer Press.

Chambers, R., \& Conway, G. (1992). Sustainable rural livelihoods: practical concepts for the 21st century. IDS Discussion 296. http://opendocs.ids.ac.uk/opendocs/bitstream/handle/123456789/775/Dp296.pdf?sequ ence $=1$

Cooper, C. a. B., Robert. (2006). Disaster: Hurricane Katrina and the Failure of Homeland Security Publishers Weekly (Vol. 253, pp. 53). New York: New York: PWxyz, LLC.

Creswell, J. W. (2018). Research design: qualitative, quantitative, and mixed methods approaches/ John W. Creswell, J. David Creswell (Fifth edition. ed.): Thousand Oaks, California: SAGE Publications, Inc.

Dent, D. (2013). Rural Planning in Developing Countries: Supporting Natural Resource Management and Sustainable Livelihoods. Hoboken: Hoboken: Taylor and Francis. 
Devine-Wright, P. (2013). Think global, act local? The relevance of place attachments and place identities in a climate changed world. Global Environmental Change, 23(1), 6169. https://doi.org/10.1016/j.gloenvcha.2012.08.003

DFID. (1999). DFID sustainable livelihoods guidance sheets. Department for International Development. http://www.ennonline.net/resources/667

Doerfel, M. L. (2015). Networked forms of organizing, disaster-related disruptions, and public health. Organizations, communication, and health, 365-383.

Doerfel, M. L., Chewning, L. V., \& Lai, C.-H. (2013). The Evolution of Networks and the Resilience of Interorganizational Relationships after Disaster. Communication Monographs, 80(4), 533-559. https://doi.org/10.1080/03637751.2013.828157

Fiksel, J. (2006). Sustainability and resilience: toward a systems approach. Sustainability: Science, Practice, \& Policy, 2(2), 14-21. https://doi.org/10.1080/15487733.2006.11907980

Fitrianto, A. R. (2019). The Socio-Economic Impacts of the Porong Mud Volcano on the Shrimp Fisheries Sector in Sidoarjo District, East Java Province, Indonesia. (Thesis (PhD)--Curtin University).

Franken, R. E., \& Bauers, P. (2002). Human motivation: Wadsworth/Thomson Learning.

Gieryn, T. F. (2002). What Buildings Do. Theory and society, 31(1), 35-74. https://www.jstor.org/stable/658136

Giesen, W., Wulffraat, S., Zieren, M., \& Scholten, L. (2007). Mangrove guidebook for Southeast Asia. Mangrove guidebook for Southeast Asia.

Hambrick, D. C., \& Fredrickson, J. W. (2005). Are you sure you have a strategy? The Academy of Management Executive, 19(4), 48-59.

https://journals.aom.org/doi/abs/10.5465/AME.2005.19417907

Harvey, M., William, F., \& Krista, E. P. (2000). History Repeats Itself, But How? City Character, Urban Tradition, and the Accomplishment of Place. American Sociological Review, 65(6), 791-823. https://doi.org/10.2307/2657514

Haywood, B. K. (2014). A "Sense of Place" in Public Participation in Scientific Research. Science Education, 98(1), 64-83. https://doi.org/10.1002/sce.21087

Hillyard, M. J. (2000). Public crisis management: How and why organizations work together to solve society's most threatening problems: iUniverse.

Iain, D.-H., \& Fikret, B. (2003). Learning as You Journey: Anishinaabe Perception of Socialecological Environments and Adaptive Learning. Conservation ecology, 8(1), 5. https://www.jstor.org/stable/26271978 
Kapucu, N. (2008). Collaborative emergency management: better community organising, better public preparedness and response. Disasters, 32(2), 239--262. https://doi.org/10.1111/j.1467-7717.2008.01037.x

Kaufman, J., \& Kaliner, M. E. (2011). The re-accomplishment of place in twentieth century Vermont and New Hampshire: history repeats itself, until it doesn't. Theory and society, 40(2), 119-154. https://doi.org/10.1007/s11186-010-9132-2

Kemmis, S. A. (2014). The Action Research Planner: Doing Critical Participatory Action Research/ by Stephen Kemmis, Robin McTaggart, Rhonda Nixon: Singapore: Springer Singapore: Imprint: Springer.

Koshy, V. (2010). Action Research for Improving Practice: A Practical Guide. London: London: Sage Publications Ltd.

Ludi, E., \& Slater, R. (2008). Using the Sustainable Livelihoods Framework to understand and tackle poverty. Poverty Wellbeing. http://www.povertywellbeing.net/document.php?itemID=2396\&langID=1

McNiff, J. (2002). Action research: principles and practice/ Jean McNiff. Abingdon, Oxon: Routledge.

McNiff, J. (2010). You and your action research project/ Jean McNiff and Jack Whitehead. London, New York: Routledge.

Menzies, J., \& Raskovic, M. (2020). Taming COVID-19 through social resilience: A metacapability policy framework from Australia and New Zealand. AIB Insights, 20(3), 18165

https://pdfs.semanticscholar.org/c2c3/bbc01651d69f7574c6f91bef2716c5e98e5c.pdf

Missimer, M., Robèrt, K.-H., \& Broman, G. (2017). A strategic approach to social sustainability-Part 1: exploring the social system. Journal of cleaner production, 140(Part 1), 32-41. https://doi.org/10.1016/j.jclepro.2016.03.170

Olsson, L., Jerneck, A., Thoren, H., Persson, J., \& O'Byrne, D. (2015). Why resilience is unappealing to social science: Theoretical and empirical investigations of the scientific use of resilience. Science Advances, 1(4), e1400217-e1400217. https://doi.org/10.1126/sciadv.1400217

Parsons, T. (1951). The social system. Glencoe, Ill: Free Press.

Pedretti, E., \& Hodson, D. (1995). From rhetoric to action: Implementing sts education through action research. Journal of Research in Science Teaching, 32(5), 463-485. https://doi.org/10.1002/tea.3660320505 
Pettit, T. J., Fiksel, J., \& Croxton, K. L. (2010). Ensuring supply chain resilience: Development of a conceptual framework. Journal of Business Logistics, 31(1), 1-21. https://doi.org/10.1002/j.2158-1592.2010.tb00125.x

Ponomarov, S. (2012). Antecedents and Consequences of Supply Chain Resilience: A Dynamic Capabilities Perspective. (Doctor of Philosophy), University of Tennessee. http://trace.tennessee.edu/cgi/viewcontent.cgi?article=2526\&context=utk_graddiss

Remoundou, K., Koundouri, P., Kontogianni, A., Nunes, P. A., \& Skourtos, M. (2009). Valuation of natural marine ecosystems: an economic perspective. Environmental Science \& Policy, 12(7), 1040-1051. https://doi.org/10.1016/j.envsci.2009.06.006

Scoones, I. (1998). Sustainable rural livelihoods: a framework for analysis Vol. IDS Working Paper 72. http://www.ids.ac.uk/files/dmfile/Wp72.pdf

Scoones, I. (2009). Livelihood perspectives and rural development. Journal of Peasant Studies, 36(1), 171-196. https://doi.org/10.1080/03066150902820503

Scoones, I. (2015). Sustainable Livelihoods and Rural Development. Practical Action Publishing. https://opendocs.ids.ac.uk/opendocs/handle/20.500.12413/13895

Scoones, I. (2016). The Politics of Sustainability and Development. Annual Review of Environment and Resources, 41(1), 293-319. https://doi.org/10.1146/annurevenviron-110615-090039

Stedman, R. C. (2003). Is it really just a social construction?: The contribution of the physical environment to sense of place. Society \&Natural Resources, 16(8), 671-685. https://doi.org/10.1080/08941920309189

Suparmoko, M. (2006). Panduan dan Analisis Valuasi Ekonomi Sumberdaya Alam dan Lingkungan (Konsep, Metode Perhitungan dan Aplikasi) [Guide and Economic Valuation Analysis of Natural Resources and Environment (Concepts, Calculation Methods and Applications)] (1 ed.). Yogyakarta: Penerbit BPFE-Yogyakarta.

Thomas, F. G. (2000). A Space for Place in Sociology. Annual Review of Sociology, 26(1), 463-496. https://doi.org/10.1146/annurev.soc.26.1.463

Vatria, B. (2013). Berbagai kegiatan manusia yang dapat menyebabkan terjadinya degradasi ekosistem pantai serta dampak yang ditimbulkannya [Various human activities that can lead to degradation of the coastal ecosystem and its impacts]. e-Journal Belian, PJ-Belian-9-1-Januari-2010. 
Williams, D. R., \& Patterson, M. E. (2007). Snapshots of What, Exactly? A Comment on Methodological Experimentation and Conceptual Foundations in Place Research. Society \& Natural Resources, 20(10), 931-937.

https://doi.org/10.1080/08941920701537015 